\title{
SISTEM PAKAR NUTRITION PLAN UNTUK ORANG DEWASA DENGAN METODE FORWARD CHAINING BERBASIS WEBSITE
}

\author{
Adang Nuryana \\ Teknik Informatika dan Komputer, Politeknik Negeri Jakarta \\ Jl. Prof. Dr. G.A Siwabessy, Kampus Baru UI, Kota Depok, Jawa Barat 16424 \\ adangnuryana7@gmail.com
}

\begin{abstract}
The problem of nutrition is still a public health problem in Indonesia. Malnutrition has not been resolved, the prevalence of overweight and obesity has begun to increase, especially in the middle and upper socioeconomic groups in urban areas. This is particularly troubling because it threatens the quality of Human Resources (HR) is indispensable in the future (Depkes RI, 2007). Changes in diet and physical activity resulted in the increasing number of people experiencing nutritional problems, such as overweight/obesity and malnutrition. Diet as the main factor nutritional problems, basically can be overcome by regulating the intake of good nutrition for consumption. But unfortunately, not many people know the setting of a good and proper diet. The Nutrition Plan was created as an expert system in determining balanced nutrition for adults based on body mass index and daily diet using forward chaining inference. This system will recommend what foods are suitable for every adult in accordance with the needs of calories per day in the hope of prevalence rates for the Indonesian people suffering from malnutrition and overweight can be reduced significantly. In addition to facilitating the public, especially normal adults to know the nutritional information in order to achieve a healthy lifestyle.
\end{abstract}

Keywords-.Expert System, Forward Chaining Method, Harris Benedict, Nutrition Plan, Berat Badan Ideal.

\section{Pendahuluan}

Masalah gizi masih merupakan masalah kesehatan masyarakat utama di Indonesia. Kekuarangan gizi belum dapat diselesaikan, prevalensi masalah gizi lebih dan obesitas mulai meningkat khususnya pada kelompok sosial ekonomi menengah $\mathrm{ke}$ atas di perkotaan. Hal ini sangat merisaukan karena mengancam kualitas Sumber Daya Manusia (SDM) yang sangat diperlukan di masa mendatang (Depkes RI, 2007).

Menurut data Hasil Riskesdas, prevalensi penduduk dewasa kurus $8,7 \%$, berat badan lebih 13,5\%, dan obesitas $15,4 \%$. Prevalensi penduduk kurus terendah di Provinsi Sulawesi Utara $(5,6 \%)$ dan tertinggi di Nusa Tenggara Timur (19,5\%). Selain itu, perkembangan teknologi termasuk teknologi pertanian, transfortasi, dan informasi, menyebabkan perubahan dalam aktivitas fisik, pola makan, dan gaya hidup. Perubahan pola makan dan aktifitas fisik ini berakibat semakin banyaknya penduduk mengalami masalah gizi, yaitu berupa kegemukan / obesitas dan kekurangan gizi.

Pola makan sebagai faktor utama permasalahan gizi, pada dasarnya bisa diatasi dengan mengatur asupan gizi yang baik untuk dikonsumsi. Namun sayangnya, tidak banyak masyarakat mengetahui pengaturan pola makan yang baik dan tepat. Gilang et all, telah membuat sistem pakar panduan gizi seimbang dengan backward chaining. Dalam aplikasi tersebut telah dibuat sebuah kepakaran untuk menghitung jumlah kalori user dan kalori setiap makanan. Berdasarkan review tersebut, dibuatnya sistem pakar penentuan gizi seimbang menggunakan inferensi forward chaining untuk orang dewasa berdasarkan indeks masa tubuh dan pola makan perharinya. Sistem ini akan merekomendasikan makanan apa yang cocok bagi setiap orang dewasa sesuai dengan kebutuhan kalori perharinya dengan harapan angka prevalensi untuk masyarakat Indonesia yang menderita kekurangan gizi, dan kelebihan berat badan dapat berkurang secara signifikan. Selain itu mempermudah masyarakat khususnya orang dewasa normal mengetahui informasi gizinya agar tercapai pola hidup sehat.

\section{Tinjauan PUSTaKa}

A. Penentuan Status Gizi

Penentuan status gizi seseorang diperoleh dari beberapa metode yaitu : 1) penilaian konsumsi 
makanan, 2) antropometri, laboratorium/biokimia dan klinis (Gibson, 2005). Diantara beberapa metode tersebut, pengukuran antropometri adalah relatif paling sederhana dan banyak dilakukan (Soekirman, 2000). Antropometri dapat dilakukan dengan beberapa macam pengukuran yaitu pengukuran berat badan (BB), tinggi badan (TB), dan lingkar lengan atas (LILA).

B. Pedoman Umum Gizi Seimbang

Pedoman Umum Gizi Seimbang (PUGS) adalah pedoman dasar tentang gizi seimbang yang disusun sebagai penuntun pada perilaku konsumsi makanan di masyarakat secara baik dan benar (Almatsier, Sunita 2011). Bahan makanan dikelompokan berdasarkan 3 fungsi utama yaitu sumber energi, sumber protein, dan sumber zat. Selain sumber makanan diatas, PUGS juga menyarankan pola makan sesuai dengan porsentase $60-70 \%$ untuk kebutuhan karbohidrat (terutama karbohidrat kompleks), 10-15\% dari sumber protein, dan $10-25 \%$ dari sumber lemak. Ketentuan tersebut dapat dibagi-bagi sesuai dengan kebutuhan kalori pagi sebesar $40 \%$, siang $30 \%$ dan malam 30\%.

C. Berat Badan Ideal

Berat badan ideal bisa dilihat dari total energi yang dibutuhkansetiap orang berdasarkan Angka Metabolisme Basal (AMB) dan aktifitas fisikyang dilakukan. Menurut (Alamtsier, Sunita 2006) AMB dipengaruhi oleh umur, gender, berat badan, tinggi, serta dinyatakan dalam satuan kilokalori (kkal). Kebutuhan kalori setiap orangdapat dihitung menggunakan berbagai rumus menurut para ahli, salah satunya berdasarkan Harris Benedict yang akan digunakan dalam penelitian ini dengan persamaan sebagai berikut :

Cara Menentukan AMB :

$$
\begin{aligned}
& \text { Laki-Laki }= \\
& \quad 66+(13,7 \times \mathrm{BB})+(5 \times \mathrm{TB})-(6,8 \times \mathrm{U})(\mathbf{1}) \\
& \text { atau : } \\
& \text { Perempuan }= \\
& 655+(9,6 \times \mathrm{BB})+(1,8 \times \mathrm{TB})-(4,7 \times \mathrm{U})(2) \\
& \text { Keterangan : } \\
& \mathrm{BB}=\text { Berat Badan dalam kg } \\
& \mathrm{TB}=\text { Tinggi Badan dalam } \mathrm{cm} \\
& \mathrm{U}=\text { Umur dalam tahun }
\end{aligned}
$$

Setelah didapatkan nilai AMB selanjutnya menentukan aktifitas fisik dengan mengacu kepada tabel I.
TABEL I

KEBUTUHAN ENERGI BERDASARKAN AKTIVITAS

\begin{tabular}{|l|c|c|}
\hline \multirow{2}{*}{ Aktivitas } & \multicolumn{2}{|c|}{ Gender } \\
\cline { 2 - 3 } & Laki-laki & Perempuan \\
\hline Sangat ringan & 1,30 & 1,30 \\
\hline Ringan & 1,65 & 1,55 \\
\hline Sedang & 1,76 & 1,70 \\
\hline Berat & 2,10 & 2,00 \\
\hline
\end{tabular}

Setelah diketahui nilai yang sesuai dengan tabel aktivitas, langkah selanjutnya yaitu mengkalikannya dengan nilai yang diperoleh dari perhitungan AMB menggunakan formulasi (3).

Kebutuhan energi $=($ nilai aktivitas fisik $) \times(A M B)(3)$

Kebutuhan energi untuk AMB diperhitungkan

\begin{tabular}{|c|c|c|}
\hline Kondisi tubuh & Kategori & Batas Ambang \\
\hline \multirow[t]{2}{*}{ Kurus } & $\begin{array}{l}\text { Kekurangan berat } \\
\text { badan tingkatberat }\end{array}$ & $<17,0$ \\
\hline & $\begin{array}{l}\text { Kekurangan berat } \\
\text { badan tingkat } \\
\text { ringan }\end{array}$ & $17,0-18,5$ \\
\hline Normal & & $>18,5-25,0$ \\
\hline \multirow[t]{2}{*}{ Gemuk } & $\begin{array}{lr}\begin{array}{l}\text { Kelebihan } \\
\text { badan }\end{array} & \text { berat } \\
\text { ringan } & \text { tingkat } \\
\end{array}$ & $>25,0-27,0$ \\
\hline & $\begin{array}{l}\text { Kelebihan berat } \\
\text { badan tingkat berat }\end{array}$ & $>27,0$ \\
\hline
\end{tabular}
menurut berat badan normal atau ideal. Cara menetapkan Berat Badan Ideal dapat menggunakan Indeks Masa Tubuh dengan aturan (4).

$$
\mathrm{IMT}=\frac{\text { berat badan }(\mathrm{kg})}{\text { ting gi badan }(\mathrm{m})^{2}}(\mathbf{4})
$$

Penilaian berat badan berdasarkan IMT menggunakan batas ambang, dapat dilihat pada Tabel II.

TABEL II

KATEGORI BATAS AMBANG IMT

Bila berat badan dinilai kurang dari berat badan ideal, maka kebutuhan energinya ditambah sebanyak 500 kkal, sedangkan bila lebih, dikurangi sebanyak 500 kkal.

\section{Sistem Pakar dan Metode Forward Chining}

Sistem pakar merupakan program komputer untuk dapat meniru proses pemikiran dan pengetahuan pakar dalam menyelesaikan suatu masalah yang spesifik. Sistem pakar banyak diterapkan untuk kepentingan masyarakat, karena dipandang sebagai cara penyimpanan pengetahuan pakar sesuai bidangnya kedalam suatu program. Sistem pakar merupakan cabang dari kecerdasan buatan dan bidang ilmu yang bekerja untuk mengadopsi pengetahuan manusia ke komputer yang menghubungkan dasar pengetahuan dengan sistem inferensi[3].

Ada dua jenis inferensi dalam sistem pakar, yaitu runut maju (Forward chaining) dan runut balik 
(Backward chaining). Dalam penelitian ini digunakan Forward chainingyang merupakan metode inferensi dengan melakukan penalaran dari suatu masalah sehingga menghasilkan solusi. Jika suatu premis dinyatakan benar (sesuai dengan situasi), maka proses akan menyatakan konklusi. Proses forward chaining akan diilustrasikan pada Gambar 1.

\begin{tabular}{lll} 
Fakta & \multicolumn{1}{c}{ Aturan } & Tujuan \\
IMT $>$ & JIKA IMT $>27,0$ & KONDISI \\
27,0 & MAKA & KELEBIHA \\
& KONDISI $=$ & BERAT \\
& KELEBIHAN & BADAN \\
& BERAT BADAN & \\
\hline
\end{tabular}

Gambar 1. Ilustrasi Runut Maju

\section{Metode Penelitian}

Dalam penelitian ini menggunakan digunakan suatu metode pengembangan sistem melaluipendekatan System Development Life Cycle (SDLC) yaitu metode Prototypingdengan beberapa tahapan pengerjaan yang ditunjukkan pada Gambar 2.

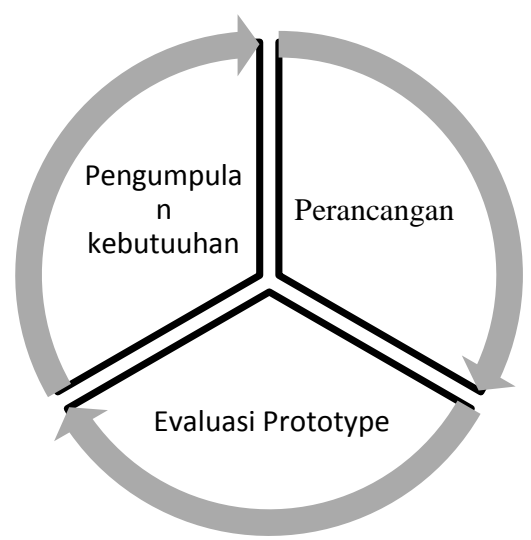

Gambar 2. Proses Prototyping

Dalam perancangan website dilakukan wawancara kepada pakar Ilmu Gizi digunakan sebagaiuser requirments. Setelah user requirments diperoleh, selanjutnya dibuatlah initial prototype, sehingga user dapat memahami bagaimana bentuk dan cara kerja website yang akan dibuat. Setelah user melihat prototype dan cara kerja website, didapatkan saran dan juga masukan mengenai webiste Nutrition Plan yang akan dijadikan sebagai bahan evaluasi dan perbaikan, sehingga website yang akan dibuat dapat disesuaikan dengan keinginan dan kebutuhan $u$ ser.

\section{HaSil Dan PEMbahasan}

Pada bab ini merupakan hasil dan pembahasan yang sesuai dengan langkah-langkah perancangan webiste menggunakan metode prototype.

Dalam pembuatan website sistem pakar Nutrition Plan, hal yang pertama dilakukan adalah melakukan interview kepada seorang pakar gizi. Dari hasil interview tersebut didapat sebuah hasil seperti terlihat pada tabel III :

TABEL IIII

DATA PERENCANAAN

\begin{tabular}{|l|l|l|}
\hline Judul & $:$ & Nutrition Plan \\
\hline Pengguna & $:$ & $\begin{array}{l}\text { Lelaki/Perempuan kategori } \\
\text { dewasa ( 18 tahun ke atas ) }\end{array}$ \\
\hline $\begin{array}{l}\text { Informasi yang } \\
\text { ditampilkan }\end{array}$ & $:$ & $\begin{array}{l}\text { Berat Badan Ideal, Indeks Masa } \\
\text { Tubuh, Jumlah Kalori/hari }\end{array}$ \\
\hline $\begin{array}{l}\text { Rekomendasi } \\
\text { Makanan }\end{array}$ & $:$ & $\begin{array}{l}\text { Dibagi kedalam 3 kelompok, } \\
\text { Makan Pagi, Siang dan Malam }\end{array}$ \\
\hline
\end{tabular}

Makanan yang ditampilkan berupa komposisi antara Karbohidrat, Protein, dan Lemak dengan porsi Pagi sebanyak 30\%, Siang 40\%, dan Malam 30\%. Harapannya dapat mempermudah pengguna khususnya orang dewasa memahami serta mempersiapkan makanan yang dikonsumsinya perhari berdasarkan pedoman gizi seimbang.

Setelah mendapatkan perancangan konsep sistem, tahapan selanjunya adalah desain sistem yang terbagi kedalam dua tahapan perancangan yaitu perancangan sistem menggunakan diagram alir, dan perancangan basis pengetahuan untuk mengetahui kesimpulan dari fakta-fakta yang sudah ada.

\section{Perancangan Sistem}

Proses perancangan sistem menggunakan bebeapa diagram alir yang mengambarkan sistem secara keseluruhan dengan berbagai fungsi yang berbeda dalam satu sistem.Tampilan aplikasi untuk menampilkan Halaman Home akan diilustrasikan dengan Gambar 3. 


\section{Sistem Pakar Nutrition Plan Untuk Orang Dewasa Dengan Metode Forward Chaining}

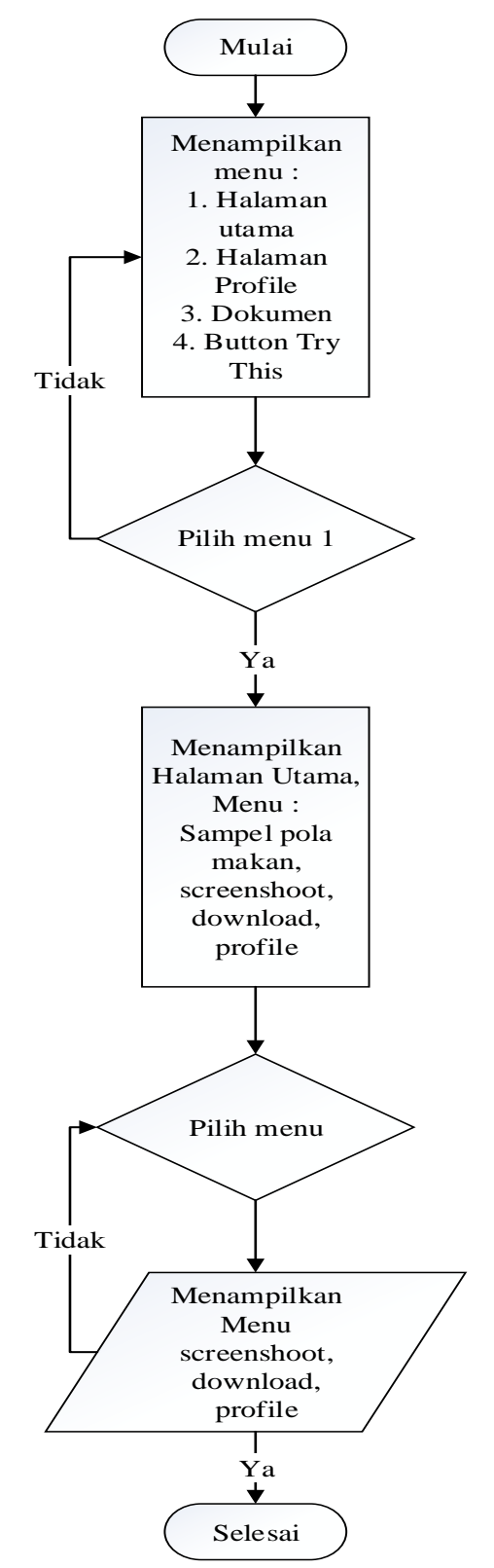

Gambar 3. Diagram alir halaman home

Diagram alir untuk Sampel Pola Makan akan diilustrasikan dengan Gambar 4.

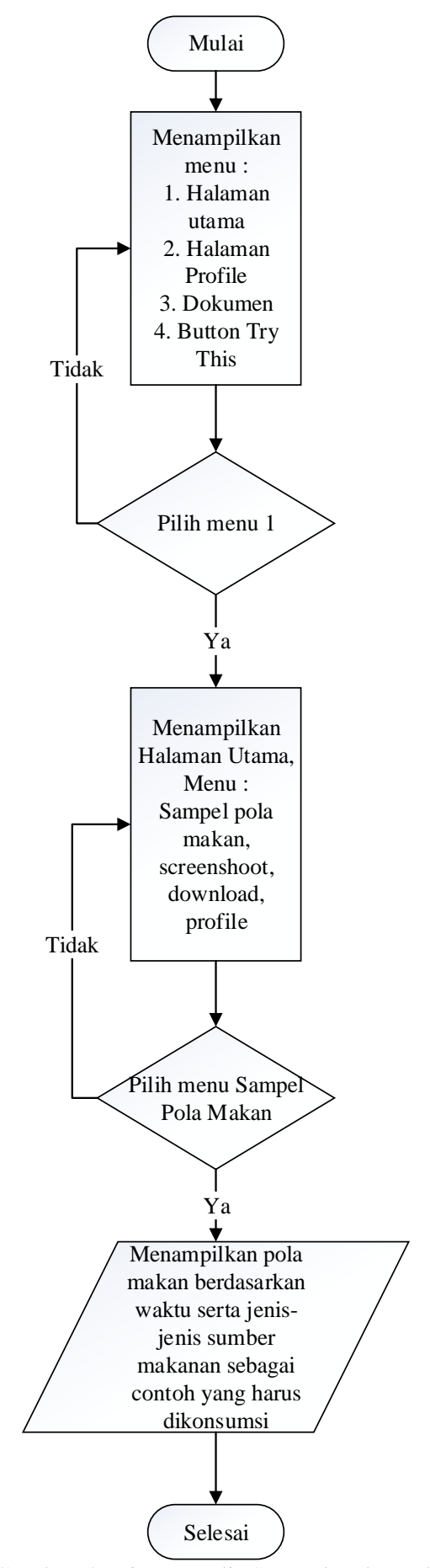

Gambar 4. Diagram alir Sampel Pola Makan 
Diagram alir untuk menampilkan Halaman

Kepakaran akan diilustrasikan dengan Gambar 5.

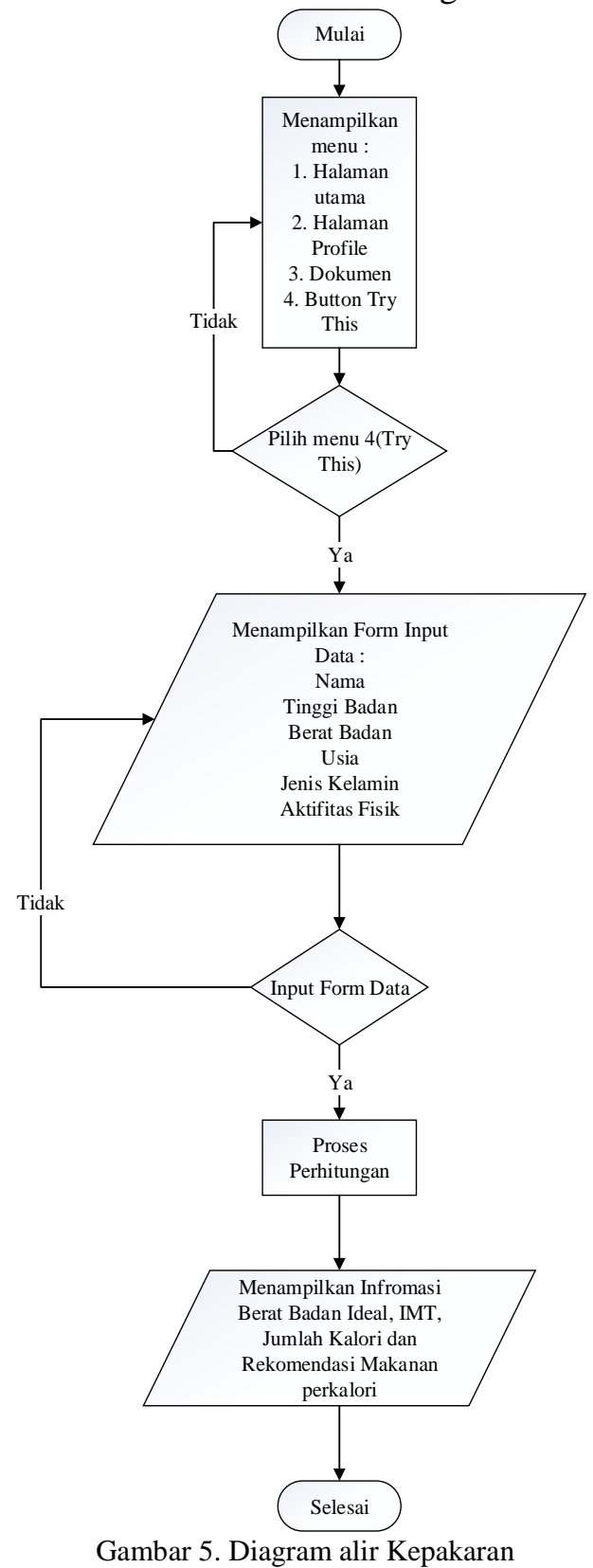

\section{Perancangan Basis Pengetahuan}

Pada tahapan ini dibuat diagram alir yang menggambarkan basis pengetahuan sistem pakar. Mesin inferensi yang digunakan dalam sistem Nutrition Plan yaitu forward chining. Berikut ini beberapa ilustrasi sederhana untuk menentukan kondisi tubuh berdasarkan ambang batas IMT dan perhitungan Indeks Masa Tubuh. Kondisi tubuh sangat kurus akan ditunjukkan pada Gambar 6.

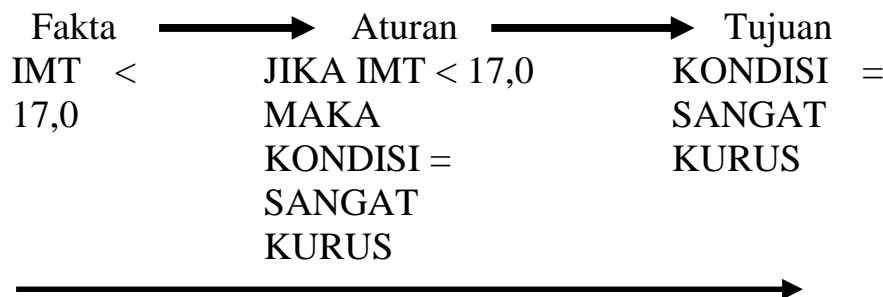

Gambar 6. Penentuan Kondisi Tubuh Sangat Kurus

Kondisi tubuh sangat kurus ditentukan apabila hasil perhitungan IMT menunjukan angka di bawah 17,0. Kondisi tubuh kurus akan ditunjukan pada Gambar 7.

\begin{tabular}{lll} 
Fakta & \multicolumn{1}{c}{ Aturan } & Tujuan \\
IMT & JIKA IMT 17,0- & KONDISI \\
$17,0-$ & 18,5 & KURUS \\
18,5 & MAKA & \\
& KONDISI = \\
& KURUS
\end{tabular}

Kondisi tubuh kurus ditentukan apabila hasil perhitungan IMT menunjukan angka antara 17,0 sampai dengan 18,5. Kondisi tubuh normal akan ditunjukan pada Gambar 8.

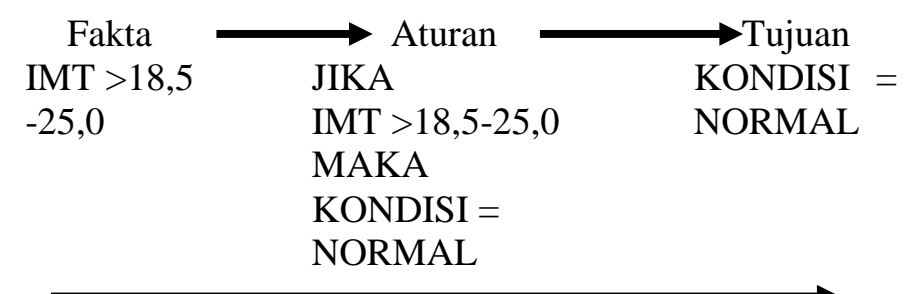

Gambar 8. Penentuan Kondisi Tubuh Normal

Kondisi tubuh normal ditentukan apabila hasil perhitungan IMT menunjukan angka lebih dari 18,5 sampai dengan 25,0. Kondisi tubuh gemuk akan ditunjukan pada Gambar 9.

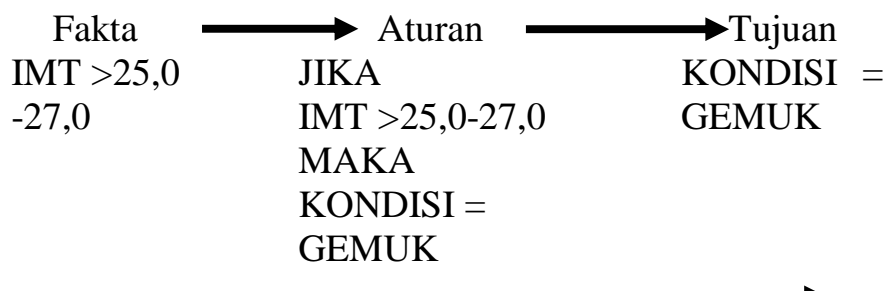

Gambar 9. Penentuan Kondisi Tubuh Gemuk 
Kondisi tubuh gemuk ditentukan apabila hasil perhitungan IMT menunjukan angka lebih dari 25,0 sampai dengan 27,0. Kondisi tubuh sangat gemuk akan ditunjukan pada Gambar 10.

\begin{tabular}{cll} 
Fakta & $\longrightarrow$ Aturan & TTujuan \\
\cline { 2 - 3 } IMT $>27,0$ & JIKA IMT $>27,0$ & KONDISI \\
& MAKA & GEMUK \\
& KONDISI $=$ & \\
& SANGAT & \\
& GEMUK & \\
\hline
\end{tabular}

Gambar 10. Penentuan Kondisi Tubuh Sangat Gemuk

Kondisi tubuh sangat gemuk ditentukan apabila hasil perhitungan IMT menunjukan angka lebih dari 27,0 .

\section{IMPLEMENTASI}

Dalam tahapan ini akan ditampilkan hasil dari implementasi perencangan sistem serta basis pengetahuan kedalam bentuk sebuah website. Ketika website dijalankan, maka akan muncul sebuah tampilan dengan nama Halaman Utamayang akan menampilkan menu utama yaitu home, profile, file, dan try this untuk proses kepakaran. Selanjutnya tampilan Halaman Home akan ditunjukan pada Gambar 11.

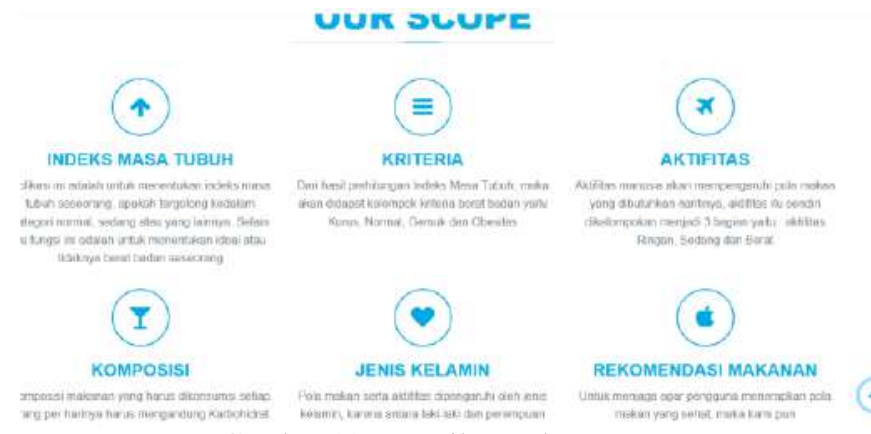

Gambar 11. Tampilan Halaman Home

Halaman ini akan menampilkan menu home dan informasi mengenai cakupan kepakaran dalam websie Nutrition Plan. Selanjutnya tampilan Halaman Sampel Pola Makanakan ditunjukan pada Gambar 12.

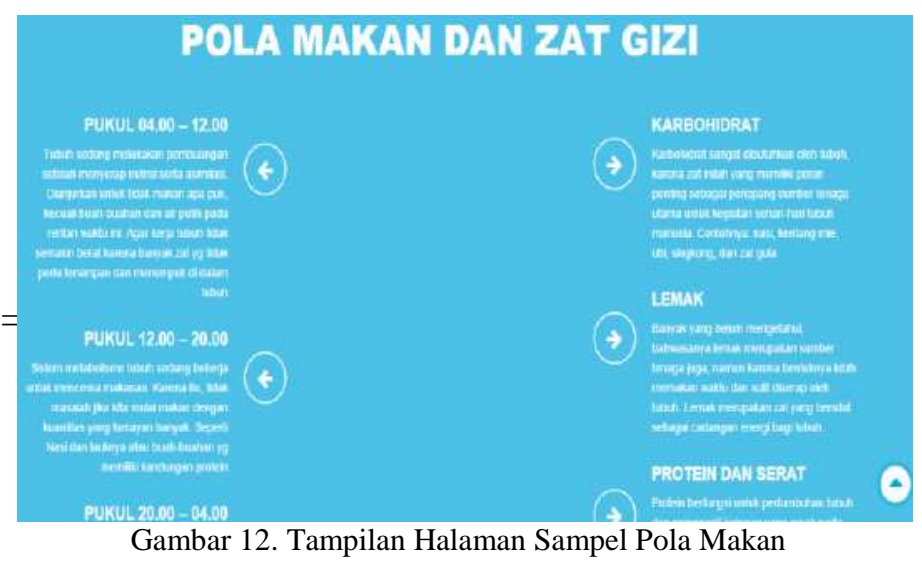

Halaman ini akan menampilkan informasi sampel pola makan yang tepat serta zat gizi yang harus terkandung dalam makanan. Selanjutnya tampilan Halaman Kepakaran akan ditunjukan pada Gambar 13.

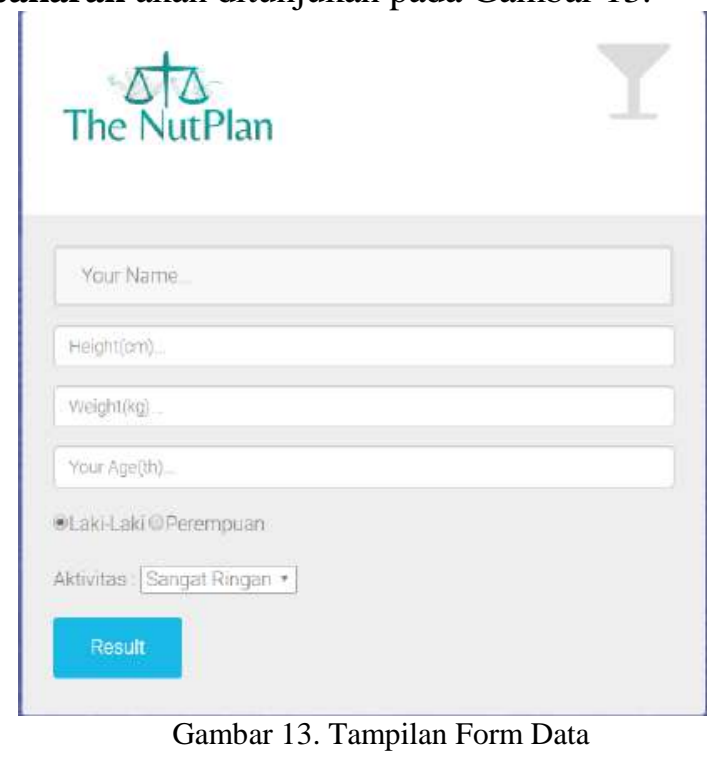

Halaman ini akan menampilkan form data yang di input user dan digunakan untuk proses perhitungan. Selanjutnya tampilan Halaman Informasi Kepakaran akan ditunjukan pada Gambar 14. 


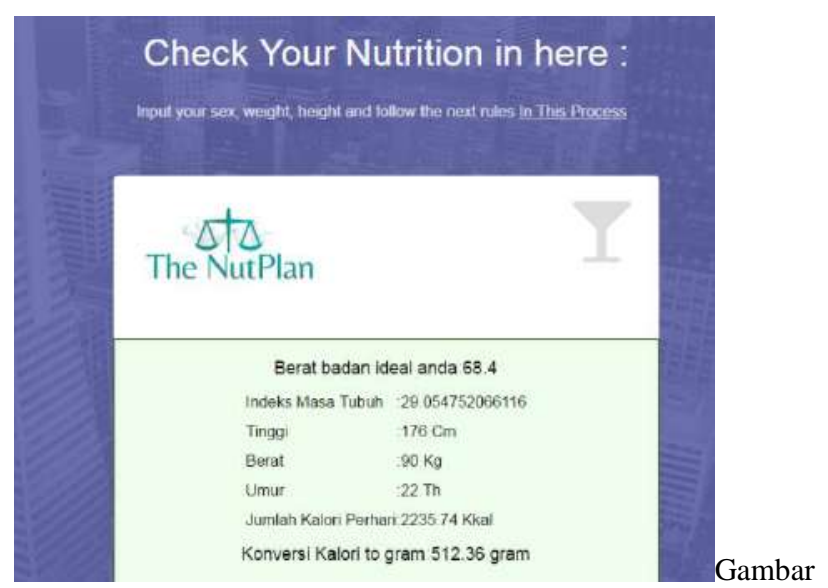

14. Tampilan Informasi Kepakaran

Halaman ini akan menampilkan hasil perhitungan dari form yang telah di input. Informasi yang ditampilkan berupa, Berat Badan Ideal, Indeks Masa Tubuh, dan Jumlah Kalori Perhari. Selanjutnya tampilan Halaman Rekomendasi Makananyang dibagi kedalam 3 bagian, Makanan Pagiakan ditunjukan pada Gambar 15.

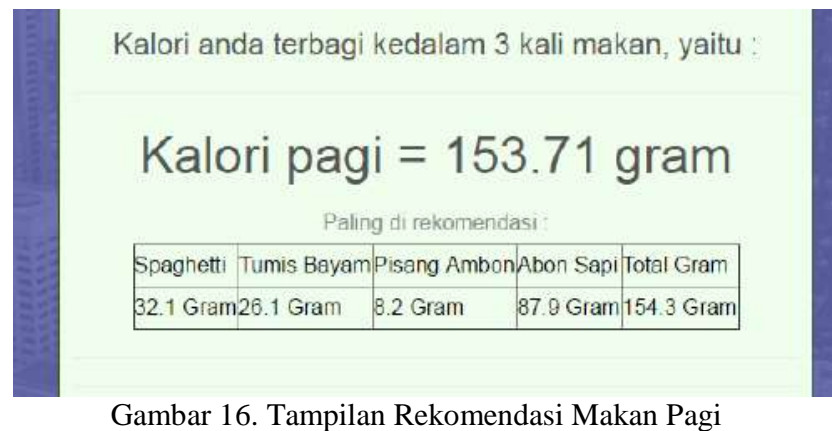

Halaman ini akan menampilkan rekomendasi makan pagi (bobot 30\% dari total kalori) sesuai dengan Pedoman Gizi Seimbang. Selanjutnya Rekomendasi Makanan Siang akan ditunjukan pada Gambar 18.

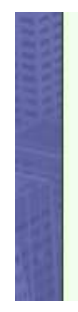

\section{Kalori siang $=204.94$ gram}

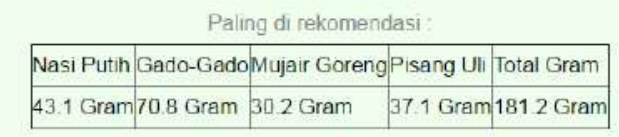

Gambar 17. Tampilan Rekomendasi Makan Siang

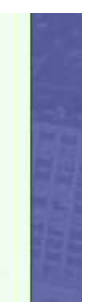

Halaman ini akan menampilkan rekomendasi makan siang (bobot $40 \%$ dari total kalori) sesuai dengan Pedoman Gizi Seimbang. Selanjutnya Rekomendasi Makanan Malam akan ditunjukan pada Gambar 18.

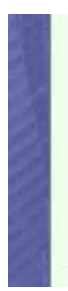

\section{Kalori Malam $=153.71$ gram}

Paling di rekomendasi

Mie Kuning GorengTahu Goreng Beef YakinikuTurnis Buncis Total Gram

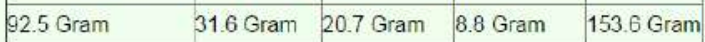

Gambar 19. Tampilan Rekomendasi Makan Malam

Halaman ini akan menampilkan rekomendasi makan malam (bobot $30 \%$ dari total kalori) sesuai dengan Pedoman Gizi Seimbang.

\section{KESIMPULAN}

Setelah menguji kesesuaian antara requirement dengan hasil website, disimpulkan bahwa metode forward chaining merupakan mesin inferensi yang sesuai dengan tujuan penelitian. Selanjutnya, hasil dari website barupa informasi Berat Badan Ideal serta Rekomendasi Makanan berdasarkan kalori per hari ini telah diuji dan diperiksa kebenaran data yang tedapat di dalamnya oleh ahli gizi pada ke akuratan memberikan informasi sesuai dengan Pedoman Umum Gizi Seimbang dan rumus Harris Benedict.

\section{Daftar Pustaka}

[5] Pembuatan Aplikasi Panduan Gizi Seimbang Berbasis Android Dengan Menggunakan Metode Backward Chaining, JTsiskomeISSN. 2338-0503 Vol 4, 2016.

[6] Rancang Bangun Aplikasi Penentuan Bahan Makanan Berdasarkan Status Gizi Pada Pasien Rawat Jalan, JSIKAISSN. 2338-137x Vol 4, 2015.

[7] Sistem Pakar untuk Mendiagnosa Penyakit Hati Menggunakan Metode Forward Chaining (Expert System for Diagnosing Liver Disease Using Froward Chaining), JUITA ISSN. 2086-9398 Vol 1, 2011.

[8] Almatisier, Sunita, "Prinsip Dasar Ilmu Gizi," Gramedia, Jakarrta. 2013.

[9] Almatisier, Sunita, "Penuntun Diet Umum," Gramedia, Jakarrta. 2013. 
Sistem Pakar Nutrition Plan Untuk Orang Dewasa Dengan Metode Forward Chaining 